Session TD4-3

\title{
Green Construction
}

\author{
Mohammed Riazuddin Mudassar \\ Civil Engineering Department \\ Lamar University Texas \\ Enno “Ed” Koehn \\ Civil Engineering Department \\ Lamar University Texas
}

\begin{abstract}
The green building revolution is sweeping construction not only in the United States but also around the world. Green construction is the latest practice that the engineers and the architects are working on around the globe in order to increase efficiency using resources such as energy, water, and materials available from nature to a maximum advantage. This should reduce the impact on human health and the environment during the building's lifecycle, through better sitting, design, construction, operation, maintenance, and removal.

The objective of the study is to emphasize the green construction phenomenon in order to educate and raise the methodology of green construction in the entire world. All types of facilities from small houses to large infrastructure projects and also commercial buildings, apartments, factories, entertainment facilities, and roads will be considered.
\end{abstract}

\section{Introduction}

Green construction is also referred as to a method of design and construction that minimizes the effect on the natural resources and the environment. Green construction includes using sustainable materials, design for lower energy use, reduced waste, and using locally available materials. This practice expands and complements the classical concerns of economy, utility, durability, and comfort. Green construction is also known as sustainable or high performance construction. $^{1}$

\section{Green Construction Origin in United States}

Some practices, such as using renewable materials, or passive solar design were used by the ancient Greeks to build their entire cities so that all the homes received solar heat in the winter. The contemporary green building movement arose out of the need and desire for more energy

Proceedings of 2009 ASEE Gulf-Southwest Annual Conference

Baylor University

Copyright (C) 2009, American Society for Engineering Education 
efficient and environmentally friendly building practices. The oil price increases of the 1970s spurred significant research and activity to improve energy efficiency and find renewable energy sources. This, combined with the environmental movement of the 1960s and 1970s, led to the earliest experiments with contemporary green building. ${ }^{6}$

\section{Green construction}

Green construction is the phenomenon opted to reduce the overall impact of the built environment on human health and the environment by:

- Efficiently using energy, water, and other resources

- Protecting occupant health and improving employee productivity

- Reducing waste, pollution and environmental degradation.

\section{U.S. green building Council}

The U.S. Green Building Council (USGBC) is a non-profit trade organization that promotes sustainability in how buildings are designed, built, and operated. The USGBC is best known for the development of the Leadership in Energy and Environmental Design (LEED) rating system and Green Build, a green building conference that promotes the green building industry, including environmentally responsible materials, sustainable architectural techniques, and public policy.

USGBC has more than 15,000 member organizations from every sector of the building industry and works to promote buildings that are environmentally responsible, profitable, and healthy in which to live and work. To achieve this it has developed a variety of programs and services, and works closely with key industry and research organizations and federal, state, and local government agencies.

USGBC also offers educational opportunities, including workshops and Web-based seminars to educate public and industry professionals on different elements of the green building industry, from the basics to more technical and advanced information. Through its Green Building Certification Institute, formerly the LEED Accredited Professional program, USGBC offers industry professionals the chance to develop expertise in the field of green building and to receive accreditation as green building professionals. ${ }^{9,10,11}$

\section{Impacts of the construction on the environment}

- $\quad$ Aspects of Built Environment:

- Siting

- Design

- Construction

- Operation

- Maintenance

- Renovation

- Deconstruction

Proceedings of 2009 ASEE Gulf-Southwest Annual Conference Baylor University

Copyright (C) 2009, American Society for Engineering Education 


\section{- Consumption:}

- Energy

- Water

- Materials

- Natural Resources

\section{- Environmental Effects:}

- Waste

- Air pollution

- Water pollution

- Indoor pollution

- Heat islands

- Storm water runoff

- Noise

- Ultimate Effects:

- Harm to Human Health

- Environment Degradation

- Loss of Resources

\section{Energy and Environmental Guidelines for Construction:}

The following guidelines are recommended:

- Specify equipment, materials, and products based on performance, not cost.

- Use recycled materials to reduce use of raw materials and divert material from landfills.

- Use local and regional materials as much as possible.

- Minimize site impact by specifying location of trailers, equipment, storage, and traffic.

- Monitor construction site energy and water use.

- Develop a construction waste management and recycling plan.

\section{Construction}

Construction design documents define the contractor's responsibilities during construction, but they typically focus on the design elements of the finished product. They rarely set environmental guidelines to be followed during the construction phase. The design team should work with the construction contractor to adopt environmental guidelines to be followed during construction.

These include the following topics:

- Construction Specifications

- Construction Materials

- Reducing site environmental impact

- Indoor air quality during construction

- Energy and water use/runoff

- Construction Waste Management and Recycling. 
Contractors seldom follow environmental guidelines during the construction process unless this guidance is built in as a written part of the contract, plans, and drawings for the building. Integrating construction guidelines with other sustainability guidelines is an essential part of the whole building design process. To develop and implement the guidelines, the contractor must work with the team, including the architect, engineers, and contractors. Creating the guidelines as a team is helpful for educating contractors about sustainability issues and getting their early commitment to follow sustainability regulations. Environmental guidelines for the construction process should include construction specifications, material specifications, indoor air quality requirements, and specific measures for reducing environmental impact energy and water usage on the site during construction.

The building's impact on energy and the environment begins during the construction phase. A sustainable approach to construction leads to reduced resource use, reduced disturbance of the site, and can also lower costs. Attention to environmental issues during construction also leads to a safer, healthier working environment for those people constructing the facility, and later for those who occupy it. ${ }^{15}$

\section{Construction Process}

1. Planning and Financing the Project

Green, sustainable, high performance - there are many names to describe a growing trend in the industry towards buildings that use less energy and fewer natural resources, cause little impact on the environment (directly and indirectly), and cost less to operate. These facilities also provide healthier indoor environments for the people who live and work in them, leading to increased productivity. Indeed, high-performance buildings benefit building users, owners, communities, states, and our nation. The following steps assist in planning the project:

- Use the whole building design approach

- Evaluate building purpose and uses and set project goals

- Review applicable codes and standards

- Plan for building commissioning

- Explore financing

\section{Design, Construct \& Renovate}

The greatest opportunities for incorporating energy efficiency and sustainability into a building occur during the design phase. During construction, there are additional opportunities to reduce the project's impact on the environment. Renovating an existing building rather than building a new facility is truly an environmental choice that does not disturb the natural environment or require new infrastructure. High-performance buildings use less energy, cost less to operate, use fewer natural resources, and impact the environment less than conventional buildings. However, the process of designing, constructing, or renovating a high-performance building may be quite different than traditional design/build methods. This section explains the key steps to successfully create a green building.

- Plan and finance the project with energy efficiency and sustainability in mind.

- Design, construct, and renovate the high-performance facilities using the whole-building approach and design tools. Topics in this section include:

o Whole Building Design

Proceedings of 2009 ASEE Gulf-Southwest Annual Conference

Baylor University

Copyright (C) 2009, American Society for Engineering Education 
o Building Siting

o Integrated Building Design

o Construction

o Renovation

- Choosing the building components that use the latest in energy-efficient technologies and practices.

\section{Building Components}

A building's components from the foundations to the roof are literally the building blocks that make the building. These components can either degrade the energy efficiency of the building or enhance its performance and increase occupant comfort.

Many new energy-saving components are coming to market. These products do double duty, performing their primary jobs while also saving energy. Roof shingles, for example, may be coated with heat-reflective materials that send the sun's heat away from the building, rather than being absorbed and can even generate electricity for the building. Compact fluorescent lights use less energy and put less heat into the building, and advances in HVAC (heating, ventilation, and air conditioning systems) technology mean more comfortable spaces that use less energy.

The benefits from these components will not be realized without being integrated into the design of the facility. Building components influence each other. To make sure they perform optimally, component performance should be modeled during the design phase. This applies to new construction as well as building renovations.

4. Operate and Maintain

When a new building is ready for occupancy, the operation and maintenance of the facility will impact energy use and occupants comfort. As much care should be paid to the operation of the building as was paid to the building planning, design and building component design. For existing facilities, effective operation and maintenance procedures provide opportunities for energy savings. Building components can be replaced with energy-efficient models. In addition the staff can be trained to cut energy use. Specifically, the following topics are to be addressed:

- Building Commissioning

- Operation and Maintenance

- Measuring Performance ${ }^{15}$

\section{Cool Roofs}

Cool roofs provide energy savings. Over $90 \%$ of the roofs in the United States are dark-colored. These low-reflectance surfaces reach temperatures of 150 to $190^{\circ} \mathrm{F}\left(66\right.$ to $88^{\circ} \mathrm{C}$ ). They have the following effects:

- Increased cooling energy use and higher utility bills,

- Higher peak electricity demand, raised electricity production costs, and a potentially overburdened power grid,

- Reduced indoor comfort,

- Increased air pollution due to the intensification of the "heat island effect"; and

- Accelerated deterioration of roofing materials, increased roof maintenance costs, and high levels of roofing waste sent to landfills.

Proceedings of 2009 ASEE Gulf-Southwest Annual Conference

Baylor University

Copyright (C) 2009, American Society for Engineering Education 
In contrast, cool roof systems with high reflectance and emittance are up to $70^{\circ} \mathrm{F}\left(39^{\circ} \mathrm{C}\right)$ cooler than traditional materials during peak summer weather. Benefits of cool roofs include reduced building heat-gain and saving on summertime air conditioning expenditures. By minimizing energy use, cool roofs do more than save money; they reduce the demand for electric power and resulting air pollution and greenhouse gas emissions.

Cool roof materials have two important surface properties a high solar reflectance and/or a high thermal emittance. Solar reflectance is the percentage of solar energy that is reflected by a surface. Thermal emittance is defined as the percentage of energy a material can radiate away after it is absorbed. Cool roofs reflect heat well across the entire solar spectrum, especially in the infrared and visible wavelengths. The less solar radiation materials absorb, the cooler they are. In addition to absorbing less heat, the coolest roofing materials radiate away any absorbed heat.

Monitoring of over 10 buildings in California and Florida demonstrates that cool roofs save residents and building owners $20-70 \%$ in annual cooling energy use. These products reduce heat transfer to the indoors, lowering air conditioning costs. ${ }^{12}$

\section{Green Roofs}

Green roofs as shown in Table 1 involve the use of water, soil, and vegetation. An alternative to traditional roofing materials is a rooftop garden. On hot summer days, the surface temperature of a vegetated rooftop can be cooler than the air temperature, whereas the surface of a traditional rooftop can be up to $110^{\circ} \mathrm{F}\left(40^{\circ} \mathrm{C}\right)$ warmer. ${ }^{4}$

\section{What Are Green Roofs?}

A green roof consists of vegetation and soil, or a growing medium, planted over a waterproofing membrane. Additional layers, such as a root barrier and drainage and irrigation systems may also be included. Green roofs can be used in many applications, including industrial facilities, residences, offices, and other commercial property. In Europe, they are widely used for their stormwater management and energy savings potential, as well as their aesthetic benefits. ${ }^{4}$

What are the Benefits of Green Roofs?

Green roofs are an attractive roofing option that can reduce urban heat islands by providing shade and through evapotranspiration, the release of water from plants to the surrounding air. They also:

- $\quad$ Reduce sewage system loads by assimilating large amounts of rainwater.

- Absorb air pollution, collect airborne particulates, and store carbon.

- Protect underlying roof material by eliminating exposure to the sun's ultraviolet (UV) radiation and extreme daily temperature fluctuations.

- $\quad$ Serve as living environments that provide habitats for birds and other small animals.

- Offer an attractive alternative to traditional roofs, addressing growing concerns about urban quality of life.

- $\quad$ Reduce noise transfer from the outdoors.

- Insulate a building from extreme temperatures, mainly by keeping the building interior cool in the summer. ${ }^{12}$ 
Table 1: Intensive and Extensive Green Roofs

\begin{tabular}{|c|c|c|}
\hline Characteristic & $\begin{array}{l}\text { Intensive } \\
\text { Green Roof }\end{array}$ & $\begin{array}{l}\text { Extensive } \\
\text { Green Roof }\end{array}$ \\
\hline Soil & $\begin{array}{l}\text { Requires minimum of one foot } \\
\text { of soil depth }\end{array}$ & Requires only 1 to 5 inches of soil depth \\
\hline Vegetation & $\begin{array}{l}\text { Accommodates large trees, } \\
\text { shrubs, and well-maintained } \\
\text { gardens }\end{array}$ & $\begin{array}{l}\text { Capable of including many kinds of } \\
\text { vegetative ground cover and grasses }\end{array}$ \\
\hline Load & $\begin{array}{l}\text { Adds } 80-150 \text { pounds per square } \\
\text { foot of load to building structure }\end{array}$ & $\begin{array}{l}\text { Adds only } 12-50 \text { pounds per square foot } \\
\text { depending on soil characteristics and the } \\
\text { type of substrate }\end{array}$ \\
\hline Access & $\begin{array}{l}\text { Regular access accommodated } \\
\text { and encouraged }\end{array}$ & $\begin{array}{l}\text { Usually not designed for public } \\
\text { accessibility }\end{array}$ \\
\hline Maintenance & $\begin{array}{l}\text { Significant maintenance } \\
\text { required }\end{array}$ & $\begin{array}{l}\text { Annual maintenance walks should be } \\
\text { performed until plants fill in }\end{array}$ \\
\hline Drainage & $\begin{array}{l}\text { Includes complex irrigation and } \\
\text { drainage systems }\end{array}$ & Irrigation and drainage systems are simple \\
\hline Source: Schlc & rth, Katrin. 2001. "Green & Stormwater Management From the $\mathrm{Tc}$ \\
\hline
\end{tabular}

\section{Components of green buildings}

EPA has extensive programs and information on green building issues, including:

- Energy Efficiency and Renewable Energy

- Water Efficiency

- Environmentally Preferable Building Materials and Specifications

- Waste Reduction

- Toxics Reduction

- Indoor Air Quality

Proceedings of 2009 ASEE Gulf-Southwest Annual Conference Baylor University

Copyright (c) 2009, American Society for Engineering Education 
- Smart Growth and Sustainable Development.

\section{Energy Efficiency}

Energy efficiency yields increased comfort, aesthetics, and productivity. There are many proven, cost-effective strategies to reduce energy use and cost in all types of buildings in various climates. Application of these strategies may result in a home or commercial space that is vastly more comfortable to live or work in.

Strategies include:

Passive solar design

- Optimize the site, design and orientation

- Landscape to provide natural shade

- Use natural day lighting

- Use natural heating and ventilation

Energy management plan

- Evaluate tradeoffs and minimize projected energy costs

- Train building occupants

- Track and optimize performance over time

- Employ an energy management system and commissioning

Energy efficient products

- Use high performance thermal insulation

- Use high performance roofing and glazing

- Use high performance lighting

- Use high performance heating, ventilation and air conditioning system

- Use high performance appliances.

\section{Water Efficiency}

Sustainable water strategies involve every aspect of water use, from stewardship of local sources to reducing use indoors and out and managing wastewater.

Conservation strategies include:

- Prepare a water use management plan

Indoor water conservation

- Use low-flow plumbing fixtures

- Use high-performance appliances

Outdoor water conservation

- Use a rainwater collection system

- Use high efficiency irrigation systems

Innovative waste water management

- Use gray water recovery systems

- Use waterless urinals.

\section{Green Building Materials}

Proceedings of 2009 ASEE Gulf-Southwest Annual Conference

Baylor University

Copyright (C) 2009, American Society for Engineering Education 
Green building materials are those which show least environmental impacts throughout their life cycle, whether measured in terms of energy used, scarce natural resources used, or air and water emissions. The strategies utilized include:

- Prepare a green building product selection plan

- Use salvaged building products

- Use recycled-content building products

- Use locally available materials

- Use rapidly renewable or naturally occurring resources

- Use certified wood

- Use structural insulated panels

\section{Waste Reduction}

Waste reduction is one of the approaches used to conserve materials in green buildings. Strategies include:

- Prepare and implement a construction waste reduction plan

- Rehabilitate existing buildings

- Demolition/deconstruction waste management

- Design to facilitate recycling and reuse

- Specify products that can be repaired or renovated instead of replaced

- Specify environmentally preferable products and practices.

\section{Indoor Air Quality}

Over the past decade, concerns over indoor air quality have been well documented, along with effective solutions. Indoor pollutants can cause building occupants to experience acute discomfort and negative health effects, such as respiratory irritation, headaches, fatigue, etc. Some substances, such as radon and carbon monoxide, can pose fatal risks. Experience and research shows that these risks can be reduced or eliminated through the following strategies:

- Ensure adaptive ventilation

- Designate indoor spaces as smoke-free

- Implement tobacco smoke controls

- Use low-emitting building products

- Install controllable systems

- Prepare an indoor air quality management plan for construction and early occupancy. 4, 5, 6

\section{LEED - Leadership in Energy and Environmental Design}

The Leadership in Energy and Environmental Design (LEED) Green Building Rating System is the nationally accepted benchmark for the design, construction, and operation of high performance green buildings. LEED gives owners and operators the tools they need to have an immediate and measurable impact on their buildings' performance. LEED promotes a wholebuilding approach to sustainability by recognizing performance in five key areas of human and environmental health: sustainable site development, water savings, energy efficiency, materials selection, and indoor environmental quality. 
LEED provides a roadmap for measuring and documenting success for various facilities and includes life cycle costs. Specific LEED programs include:

- New Commercial Construction and major Renovation projects

- Existing Building Operations and Maintenance

- Commercial Interior Projects

- Core and Shell Development projects

- Homes

- Neighborhood Development

- Guidelines for Multiple Buildings and On-Campus Building Projects

- LEED for Schools

- LEED for Retail

\section{LEED Certification}

The first step in order to obtain LEED certification is to "Register" the project. A project is a viable candidate for LEED certification if it can meet all prerequisites and achieve the minimum number of points to earn a particular level of project certification. To earn certification, a facility must meet certain prerequisites and performance benchmarks ("credits") within each category. Projects are awarded Certified, Silver, Gold, or Platinum certification depending on the number of credits they achieve. This comprehensive approach is the reason LEED-certified facilities have healthier and more productive occupants, conserve natural resources, and reduce operating costs. ${ }^{9}$

LEED Performance Levels

Certified

Silver

Gold

Platinum
Number of points

26 to 32

33 to 38

39 to 51

52 to 69

These points are awarded based on the following parameters

- Sustainable sites: 14 possible points.

- Water efficiency: 05 possible points.

- $\quad$ Energy \& Atmosphere: 23 possible points.

- Materials \& Resources: 16 possible points.

- Indoor air quality: 22 possible points.

- Innovation: 05 possible points.

Where the points are in LEED

\begin{tabular}{lcc} 
Category & Possible points & $\%$ of the total points \\
Sustainable sites & 14 & $(20 \%)$ \\
Water efficiency & 5 & $(07 \%)$ \\
Energy/atmosphere & 17 & $(25 \%)$ \\
Materials/resources & 13 & $(19 \%)$ \\
IEQ (indoor environmental quality) & 15 & $(22 \%)$ \\
Innovation & 4 & $(06 \%)$ \\
\multicolumn{4}{c}{ Croceedings of 2009 ASEE Gulf-Southwest Annual Conference } \\
& Baylor University \\
& Copyright $@$ 2009, American Society for Engineering Education
\end{tabular}


Accredited professional 1 (1\%)

Total 69

Green Roads

$(100 \%)$

A green highway integrates transportation functionality and ecological sustainability ${ }_{2}$ the result is a highway that will benefit transportation, the ecosystem, urban growth, and surrounding communities. Green Roads is a proposed standard for quantifying sustainable practices associated with the design and construction of roads. It is a rating system that awards credits for approved sustainable choices/practices which can be used to certify roadway projects based on the total credits earned. Such a standard can (1) allow informed sustainability decisions, (2) provide a quantitative means of sustainability assessment, (3) stimulate improvement and innovation in roadway sustainability, and (4) provide baseline to sustainability standards. Green Roads consists of 53 credits in 6 categories that can be used to achieve certification.

\section{Definition:}

Green highways are:

- built with permeable materials that provide superior watershed driven storm water management, thus preventing metals and toxins from leaching into streams and rivers

- constructed with recycled materials, thereby reducing landfill usage

- Designed using cutting-edge technologies to protect critical habitats and ecosystems from the encroachment of highway infrastructure.

\section{Qualities of Green Roads:}

Though this is not an exhaustive list, green highway qualities include:

- Providing a net increase in environmental functions and values of a watershed.

- Going beyond minimum standards set by environmental laws and regulations.

- Identifying and protecting historic and cultural landmarks.

- Mapping all resources in the area in order to avoid, identify, and protect critical resource areas.

- Using innovative, natural methods to reduce imperviousness, and cleanse all runoff within the project area.

- Maximizing use of existing transportation infrastructure, providing multi-modal transportation opportunities, and promoting ride-sharing/public transportation.

- Using recycled materials to eliminate waste and reduce the energy required to build the highway.

- Linking regional transportation plans with local land use partnerships.

- Controlling populations of invasive species, and promoting the growth of native species.

- Incorporating post project monitoring to ensure environmental results.

- Protecting the hydrology of wetlands and streams channels through restoration of natural drainage paths.

- Resulting in a suite of targeted environmental outcomes based upon local environmental needs.

- Reducing disruptions to ecological processes by promoting wildlife corridors and passages in areas identified through wildlife conservation plans.

Proceedings of 2009 ASEE Gulf-Southwest Annual Conference

Baylor University

Copyright (C) 2009, American Society for Engineering Education 
- Encouraging smart growth by integrating and guiding future growth and capacity building with ecological constraints. ${ }^{13,14}$

\section{Build green and save green Ways to green a building before and after construction}

\section{"Things that cost the same or less"}

1. The single most important things you can do to help the environment and your wallet is to size the building appropriately. The smaller the building the more energy, materials and money you save. That can help you to afford some extra insulation or solar panels.

2. Let the Sun be your friend by facing the building towards the south and putting most of the windows on the south side you can let the sunlight up your home during the day and warm the house in the winter. Planting trees on the south side and extending the roof's eaves can block out the sun's rays in the summer to keep the house cool.

3. Buy locally. This saves massive amounts of gas used to transport construction materials around the country and the world.

4. Recycle your construction waste instead of sending it to the dump. Taylor recycling in Montgomery, NY can provide a dumpster that will recycle up to $99 \%$ of the waste produced. Make sure you have separate bins or boxes for recyclables to make it super easy for everyone. 35\% of the waste in landfills is recyclable paper and paperboard. Only $22 \%$ of glass waste is recycled. About $40 \%$ of aluminum is recycled. And recycle your food too. Start a compost bin (or a worm bin) for all vegetable and garden waste. 10\% of the waste in landfills is food.

5. Use dual-flush toilets. $40 \%$ of the water used at homes goes right down to the toilets. Dualflush toilets let you to choose whether you need a big or a little flush. This simple choice saves about 6000 gallons of water per year for a family of four. Low-flow shower and sink fixtures will save additional water.

\section{Pay now, save Later- "Things that save the earth and save our money over time"}

6. Location, location, location... Think carefully about where you build. Is it close to where you work, shop and play? You may pay more up front for a location in town, but you will save tons in gas money.

7. Effective insulation is the most cost-effective energy saver. No use getting fancy things like solar panels if your home leaks energy. Try to use energy star windows with a low-E coating. Pella designer series windows are currently the most energy efficient windows that are widely available.

8. Use energy-efficient lights. Compact fluorescent bulbs use 66\% less energy and last 5000 hours, ten times longer than a regular incandescent bulb. Cold cathode lights use the same energy as compact fluorescents but last an incredible 25,000 hours and can be used outside. If every U.S. household replaced just one light bulb with a compact fluorescent or cold cathode bulb, it would prevent enough population to equal removing one million cars from the road.

马. Choose appliances with energy star symbol. Install Energy star ceiling fans, Casablanca is brand that offers a wide variety of quality fans. This will cut costs by circulating heat in the winter and cooling air in the summer. These appliances use 10-50\% less energy than a

Proceedings of 2009 ASEE Gulf-Southwest Annual Conference Baylor University

Copyright @ 2009, American Society for Engineering Education 
standard appliances and can save about \$80/year. If one in ten homes used energy star appliances the change would be like planting 1.7 million new acres of trees.

10. Include a root cellar into your home design. Root cellars keep vegetables and fruits fresh without refrigeration and increase your storage capacity. That allows you to buy and store lots of food when it's in season and use it later. That supports local farmers and save massive amounts of gas. In United States food travels an average of 1500miles miles before it reaches its final destination. Almost 50\% of the food transported is lost to spoilage.

II. Use solar panel and leave out the batteries. Solar panels can help you avoid the massive environment and social ills of coal, nuclear, natural gas, and big dam projects. New York State will foot half the bill, and New York allows you to "net meter". That means you stay connected to the electric grid and any time you produce more electricity you use, it gets sent into the grid for someone else to use and your meter runs backward, so you are a part of helping provide clean energy to your neighbors. And when you need more energy what your panels produce, you just draw from the grid like normal. This allows you to not use batteries, which are not so good for the environment, add a lot to the cost, and can only store so much energy before any extra is just lost.

12. Install geothermal heating and cooling. A geothermal system uses the earth's constant underground temperature to cool and heat your house, as well as provide all of your domestic hot water. It uses about 50\% less energy to heat your home and about $25 \%$ less to cool it.

13. Use no-VOC and low-VOC primers, paints, sealants, and carpets. Volatile organic compounds can irritate eyes and throat, cause headaches and fatigue, damage major organs, and cause cancer. AFM safe coat is one company that makes only no and low-Voc products.

\section{"Some things that just cost more to do right - but do them anyway"}

14. Plug the gaps in your home that allow heat to escape. This could save up to $10 \%$ of your utility bills. Install weather-stripping around exterior doors and long thresholds. If the gap at bottom of a door is high, install a door sweep. Use expanding foam to seal gaps around pipes that enter your house from the outside. Check the joints and insulation on the ducts of your heating/ventilation/air conditioning system. Fix any leaks with mastic sealant. Make sure your water heater is wrapped in an insulation jacket, particularly if the units are in unheated area of the house. And definitely keep fireplace dampers closed when not in use.

15. When you need to replace the roof, consider a metal roof. They are long-lasting, often made of highly recycled material, help to deflect heat in the summer, and recyclable. Asphalt shingles are short-lived made of oil, rarely recycled, and gives off toxic VOCs which can be drawn into the house. If you have to go with asphalt, make sure you go with 50-year asphalt shingles with recycled content. Regardless, never drink water coming off an asphalt roof.

16. Avoid PVC (vinyl) as much as possible. Dioxins are a byproduct of PVC. They also happen to be the most toxic substance on the planet, known to cause cancer, neurological damage, birth effects and more. In the US PVC is manufactured predominantly near lowincome communities in Texas and Louisiana. Due to illegal dumping, mishandling, and burning, dioxins are now found all around the world. Dioxins exposure of the average American poses a risk of cancer of greater than 1 in 1,000. PVC releases deadly gases in

Proceedings of 2009 ASEE Gulf-Southwest Annual Conference Baylor University

Copyright (C) 2009, American Society for Engineering Education 
fire, including one that turns to hydrochloric acid if inhaled. PVC is not biodegradable and less than $1 \%$ can be recycled.

17. Buy FSC-certified wood. The forest stewardship council provides independent audits that assure the wood you buy was not stolen from protected lands or lands of indigenous people without their consent. The FSC label also means wood was not taken from fragile ecosystem, that it was harvested sustainably, and that local community's benefit from the process.

18. Buy green power or offset your carbon emission. In New York State you can choose who supplies your electricity and there are many companies that use renewable sources, such as solar, wind and hydro power. It's very easy and reliable to switch. ${ }^{2,3,7,8}$

\section{CONCLUSION}

Implementing the foregoing strategies can assist in utilization of the land, water, energy, and other resources efficiently. Innovation techniques are always invited by the construction industry aiming for improved environmental sustainability in the future. It enhances human health, strengthens economies and communities, and also conserves plants, animals, endangered species, natural habitats and helps in protecting agricultural, cultural, and archeological resources. Hopefully, this approach will become the standard method utilized to construct facilities in years to come and will spread around the world.

\section{Acknowledgement}

The authors wish to recognize Mr. Manish Dua for his assistance with the activities involved in preparing this paper. 


\section{References}

1. http://en.wikipedia.org/wiki/Green_building [Accessed on July 2008]

2. http://www.commonfire.org/community/greenwelcome.html [Accessed on July 2008]

3. http://www.commonfire.org/community/greenwelcome.html [Accessed on July 2008]

4. http://www.epa.gov/greenbuilding/pubs/components.htm [Accessed on July 2008]

5. http://www.epa.gov/greenbuilding/pubs/buildingtypes.htm [Accessed on July 2008]

6. http://www.epa.gov/greenbuilding/pubs/about.htm\#1 [Accessed on July 2008]

7. http://www.commonfire.org/community/15existing.pdf [Accessed on August 2008]

8. http://www.commonfire.org/community/17new.pdf [Accessed on August 2008]

9. http://www.usgbc.org/ [Accessed on July 2008]

10. http://www.usgbc.org/DisplayPage.aspx?CategoryID=19 [Accessed on July 2008]

11. http://en.wikipedia.org/wiki/United_States_Green_Building_Council_Accessed on July 2008]

12. http://www.epa.gov/heatisland/strategies/coolroofs.html [Accessed on July 2008]

13. http://pavementinteractive.org/images/e/e6/Green_roads_summary.pdf [Accessed on August 2008]

14. http://pavementinteractive.org/index.php?title=UW:Green_Roads[Accessed on August 2008 ]

15. Building and Buying Green in Indian Country-A Practical Guide For California Tribes, May 2004. [Accessed on august 2008].

Enno Koehn, Lamar University

Dr. Enno Koehn is professor of Civil Engineering at Lamar University. Dr. Koehn has served as the principle investigator for several research and development projects dealing with various aspects of construction. He also has experience in the design, scheduling, and estimating of facilities. He has authored/co-authored over 200 papers in engineering education, as well as the general areas of civil and construction engineering. Dr. Koehn is a member of ASEE, AACE International, ASCE, NSPE, Chi Epsilon, Tau Beta Pi, Sigma Xi, and is a registered Professional Engineer and Surveyor.

Mohammed Riazuddin Mudassar, Lamar University

Mohammed Riazuddin Mudassar is a Civil Engineering Graduate student. He has one year of experience working for a consultant in Structural Design and analysis. He has written couple of papers in his under graduation. Mohammed Mudassar is student member of ASCE and International member of ASTM.

Proceedings of 2009 ASEE Gulf-Southwest Annual Conference

Baylor University

Copyright (C) 2009, American Society for Engineering Education 
Proceedings of 2009 ASEE Gulf-Southwest Annual Conference Baylor University

Copyright (C) 2009, American Society for Engineering Education 